\title{
AN ANALYSIS OF MORAL AND EDUCATIONAL VALUES ON MADURA FOLK SONGS
}

\author{
Abd. Wakil (corresponding author) \\ Department of Language and Literature, Kanjuruhan Univrsity of Malang \\ Jl. Kepuh Utara No. 47 A Malang, East Java, Indonesia \\ Phone: $081949948454 \quad$ E-Mail: amenwaki@gmail.com
}

\begin{abstract}
At this moment traditional songs was not pay attention so that almost the traditional song is not well known by young generations. The position of traditional songs was lost with technology. If there is not an conservation and appreciation for traditional songs especially Madura traditional songs, so the traditional song can be lost in the future so that writer try to analysis of moral and educational values on Madura folk songs.
\end{abstract}

The discussion in this thesis the author tried to review the pedagogical values particularly with regard to the morality contained in the lyrics of Madura folk song. The author only took eight songs contained in a book of poetry titled Madura folk songs "set song Madura Regions" in 2003 by the author R. Amirudin Tjitraprawira Namely; "Lir Saalir", "Tondu' Majang”, "Pajjhar Langgu”, "Caca Aghuna”, "Pa'-Opa' Iliing”, "Pacakang Alako”, "Entar Akarang”, "Les Balesan”. The research was conducted with the following statement of problems: (1) What are moral and educational values found on Madura folk song by R. Tjitraprawira? (2) How is the meaning of Madurese life which is contained in the Madura song lyric? (3) What are the messages that can be delivered to the reader on Madura folk song by R.Amiruddin Tjitraprawira?

The objective of this study was to know moral value found on madura folk song, to know how the meaning of madurese life which is contained in the madura song lyric,to know the message that can be delivered to the reader of madura folk song by R.Amiruddin Tjitraprawira.

The researcher uses descriptive qualitative approach in finding moral and educational values. The research method is used from the researcher itself because for analysis the data use interpretation of own words. The data is taken eight titles from Madura songs such as "Lir Saalir", "Tondu' Majang", "Pajjhar Langgu”, “Caca Aghuna”, “Pa'-Opa' Iliing”, “Pacakang Alako”, “Entar Akarang”, “Les Balesan”. The researcher choose this titles because it contains the high valuable meaning related Madura daily activities which is designed in madurese language.

Finally, this study uses semantic as the base theory which related on moral and educational values. Therefore, the researcher suggests to the next researcher whom want concern with the similar topic to analyze moral and educational values should be attention the theory which accordance with the research object itself and look for references that can be found in journal, newspaper, and books, etc.

Keyword : Moral and educational values, Madura folk song 


\section{Introduction}

Madura folk songs have been counted along with the song quite old Javanese, Sundanese and Malay. Madura folk songs are representation or manifestation of almost all social and cultural values of the Madurese including as a medium of education to maintain self-existence of Madurese in the next generation. In other words, the song is a means of transforming the value of Madura.

Madura lyric folk songs can be classified in a half oral literature because the expression accompanied by music. Hutomo (1991) stated that oral literature is divided into two parts namely the pure oral literature and half oral literature. Definition of pure oral literature is oral literature spoken purely by word of mouth. While half of pure oral literature is narrative of oral literature that assisted with other art forms. Accompaniment of Madura folk songs generally are typical of music, thus song and art Madurese folk music has style specificity and can reflect the social life of the community population. Madura folk song is one form of social and cultural of Madura society. Unfortunately respect and appreciation of the people on Madura songs still fairly low, so it is only seen as a work culture that does not have an important role in building the Madurese. In fact, if the song Madura studied more in depth, meaning either contained or reference to hold onto life for the people of Madura, and will be visible community identity and values wisdom Madura.

Aspects of education and morality contained in the lyrics of the Madura folk song noteworthy because Madura folk song can bring a positive influence when used within the scope of pedagogy. Psychological aspects and pedagogical aspects contained in
Madura folk songs are very large if it is really seen as a potential means of innovative and pedagogy related issues.

The discussion in this thesis the author tried to review the pedagogical values particularly with regard to the morality contained in the lyrics of Madura folk song. Noble values in Madura song can be seen from some of the songs that are often used by people of Madura, which is known for folk songs. In this case, the authors only took five songs contained in a book of poetry titled Madura folk songs "set song Madura Regions" in 2003 by the author R. Amirudin Tjitraprawira Namely; "Lir Saalir", "Tondu' Majang”, "Pajjhar Langgu", "Caca Aghuna”, "Pa'-Opa' Iliing”, "Pacakang Alako”, "Entar Akarang”, "Les Balesan”.

\section{Literature review Definition of Moral Value}

Definition of moral according to Suseno (1998) is a measure of one's merits both as individuals and as citizens. While moral education is education for the children in moral and humane. Meanwhile, according to Ouska and Whellan (1997) is a moral principle that there are good-bad and inherent within the individual / person. Moral value are divided into two categories that are good and bad moral value.

1. Good moral value

According to Imam Sukardi (2013) Good moral value is a good behavior in accordance with the size - the size of the actions that can be accepted by the public include the unity of a particular social or environmental. Arcient Greece (Lilik, 2000) considered as quality characteristic makes someone right in terms of characters and in their mind. According to Socrates (Sofa, 2011) good is a kind of 
wisdom that lead to harmony in one's life like healthy, beauty and well-being of the spul. According to Aristotle (Sofa, 2011) good is a matter of the state of the typical advantages and allow it to discharge its functions properly. Classification of goodness :

a. Aristotle (Sofa, 2011) classifies good into goodness of moral and goodness intellectual which consists of the following terms:(1) Restrictions (2) Fortitude (3) Justice (4) Wisdom (5) Science (6) Intuitive sense (7) Art

b. Thomas Aquinas (Sofa, 2011) theological goodness consists of the following terms :(1) Confidence (2) Hope (3) Lov

\section{Bad moral value}

Bad moral value is behavior which is very disturbing safety in the environment and could have hurt others. According to KBBI (2013) bad moral value is act or attitude which is not acceptable in our society laws and regulations. Persons with a Bad or wrong moral values usually they also have problems with the law. Terror, theft, kidnapping and abuse that are some examples of bad or wrong moral value. According to Imam Sukardi (2013) bad moral value is a behavior that does not match the size of the public actions of a particular environment. According to Al - Gazali (wikipedia, 2013) bad moral value is behavior that violates the rules of society and can harm other people.

\section{Definition of Educational Value}

Education encompasses teaching and learnin $\mathrm{g}$ specific skills, and also something less tangible but more profound: the imparting of knowledge, positive judgment and welldeveloped wisdom. Education has as one of its fundamental aspects the imparting of culture from generation to generation (see socialization). Education means 'to draw out', facilitating realization of self-potential and latent talents of an individual. It is an application of pedagogy, a body of theoretical and applied research relating to teaching and learning and draws on many disciplines such as psychology, philosophy, computerscience, li nguistics, neuroscience, sociology and anthr opolog.

\section{Song Lyric}

According to Abram (1999:146), "lyrics in the most common use of the term, a lyric is any fairly short poem". Lyric provides guidelines to the development of ideas expressed by the composer to the listener that make them understand the ideas inside the lyric. The listener will be able to undertsand what the composer is going to share and what is going on. Lyrics is the one way how the composer express their personal experience. According to Lewis (1961:2), "song lyric is the lyre, meant to be sung that directly expresses thoughts and sentiments and it can be a cry straight from the heart". Song lyrics are texts that consist of elements that make them accurate by the composer consisting of message.

According to Routledge Dictionary (2006: 132) "the lyric was originally a song set to the lyre, and later to other musical instruments. The lyrics are verbal symbols created by man. Humans are creatures that know how to react, not only to the physical environment, but also the symbols of its own.(Rivers, 2003:28). Song lyric is an expression of a person about a thing that is seen, heard and experienced firsthand. In expressing his experience, poet or songwriter doing plays on words and language to create attractiveness and distinctiveness to the lyrics or poem. 
Methodology

Research Design

This study is designed to be a descriptive qualitative method. Qualitative research method is used because it does not deal with numbers and statistically computation like those in quantitative research. And this study aims at observing and describing the moral value of Madura folk song. And the object of this study is song lyric.

3.1 Data and Data Sources

In Madura folk songs lyrics contain many kinds several of meanings. The several of meanings in Madura folk song lyrics such as relate to patriotism, religion, feminism, nationalisms, and etc. Many Madura folk song lyrics which provide in Madura culture are very famous such as follow as: Lir Saalir, Tondu' Majang, Pajjhar Langgu, Caca Aghuna, dan Pa'-Opa' Iliing, kerabhan sape, tera' bulan, taresna, kembhenga nagere, es lilin cabbi etc. From Madura folk song list above, researcher clarifies Madura folk song lyrics written by R. Amirudin Tjitraprawira. The researcher finds eight Madura folk song lyrics such as "Lir Saalir", "Tondu' Majang”, "Pajjhar Langgu”, "Caca Aghuna”, "Pa'-Opa' Iliing", "Pacakang Alako", "Entar Akarang", "Les Balesan" to be analyzed. It is caused by eight lyrics written by R.Amiruddin Tjitraprawira contain sense which related Nationalism, Patriotism, and Morality.

\section{Data Collection}

The data are collected from those eight Madura folk song lyrics written by R.Amiruddin Tjitraprawira. After that, the researcher uses technique how the process of collecting data as follows: (1) Reads carefully and tries to understand the lyrics from those eight Madura folk song lyrics written by
R.Amiruddin Tjitraprawira . (2) Verifies the data are appropriate with the study. The study which is taken by researcher related the statement of problem.

\section{Instruments}

A research instrument is what you use to collect the information in a qualitative field study or observation. It helps you keep track of what you observe and how to report it. It must be both valid and precise. The main instrument of the study is the writer himself as the researcher. In this literary study the writer is the one who interpreted and analyzed the data. The writers developed the researcher question and the source of the study like thesis, documentation of literary books, and internet.

The researcher go to library at Kanjuruhan University of Malang, EAC (English Access Center) of Kanjuruhan University of Malang, and Pamekasan library, Malang University of Malang. Before describing the moral value, the researcher studied about value and message on the Madura folk song especially the moral and educational value. After that, the reseacher described the moral values of each folkl song and the reseacher wrote the message can be delivered to the reader of the moral and educational value of the folkl song after understanding and comprehending the folkl song.

\section{Data Analysis}

According to Steinbeck (1988:21) there are three concurrent flows of activity needed in conducting qualitative data analysis, but there is one which accordance with the researcher's study of data display is an organized assembly of information that permits drawing and action taking. After analyzing whole data founded from the lyrics, the researcher displays the result of the analysis on the 
descriptive form based on each category of moral value.

Accordance from that theory, the researcher tries to classify the Madura folk song lyrics to be eight song lyrics. After that, the researcher uses technique how to analyze the data as follows:(1)Finding and selecting of Madura folk song written by R.Amiruddin Tjitraprawira .(2)Translating the original data in Madura language into Indonesian language. (3) Changing the data in Indonesian language into English language. (4) The resercher identifying moral and educational value that is found in each of folk song. (5) The researcher tries to find the messages that can be delivered to the reader. (6) Rechecking the data. (7) Taking conclusion of the data.

\section{Result and Discussion \\ Result \\ Madura folk song lyrics}

\section{Tondu majang}

Ngapote wak lajereh e tangaleh, Reng majeng tantona lah pade mole Mon e tengguh deri abid pajelennah, Mase benyak'ah onggu le ollenah Duuh mon ajelling odiknah oreng majengan,

Abental ombek asapok angin salanjenggah Ole...olang, paraonah alajereh, Ole...olang, alajereh ka Madure Reng majeng bennya' ongggu bebejenena, Kabileng alako bendhe nyabenah. Ole...olang,

Paraonah alajereh, Ole...olang, Alajereh ka Madureh...

The song " Tondu ' Majang " has a deep meaning about the character of Madurese community in carrying out their daily life as a fisherman. Their lives as fishermen are very hard because they have to face the dangers of the sea. They must struggle in the sea to fulfill their needs and families although they have to stake their life (bhandha nyaba). For getting a lot of fish they have to spend the night on the boat all around night and day with waves and wind like they sleep using covered wave and wind (abhantal omba' asapo' angin).

\section{Pajjar Lagghu}

Pajjhar langghu arena pon nyonara Bapa' tane se tedung pon jhagha'a Ngala' are' ben landhu' tor capengga A jhalananna ghi' sarat kawajibhan Atatamen mabannya' hasel bhumena Mama'mor nagharana tor bangsana Pajjhar Lagghu song is a representative of the social conditions of the farmers in Madura. In this song told that the farmers go to the fields since daybreak with a passion for farming. "Pajjhar Lagghu" (fajar pagi) is a song that describes the dawn in the morning. When dawn came, the sun was rising indicates that it is time for farmers to go to the fields and fields. The farmers go to the field with a hoe and a hat to carry out work in order to support his family.

\section{PA' OPA' ELING}

$P a^{\prime}$ opa' eling elingnga sakoranji eppa'na olle papareng ana' tamba tao ngaji ngaji babana cabbi ka'angka'na sarabi potthon e cocco' dhangdhang pote keba mole e cocco' dhangdhang celleng keba melleng

As madures society that upholds the values of religion, Madurese society always require their children to learn the Al-Quran which is a tool to deepen their religious knowledge later when they become adults. In addition, this song describes the social conditions of a 
family between parents and their children. The song above also revealed that the duties of parents have to work hard in order to their children will become smart children.

\section{Lir saalir}

Lir saalir, alir alir, kung!

Ngare' belta ngeba sada

Mon motta esambi keya,

Lir saalir, alir alir, kung!

Tada' kasta neng e ada'

Ghi' kasta e budi keya,

Lir saalir, alir alir, kung!

Perreng pettong pote-pote

Reng lalakon patengate...

This song was suggested to us to think clearly before taking action, making decisions or other critical actions. If we make some mistakes in taking action or decide something we will be regret later (Tada'kasta neng Eada', Ghi' kasta e budi Keya). So we are required careful in the act and behave so as not to regret in the future.

\section{Caca Aghuna}

Ya' tampar ya' tampar, mulet nyono' ka cengkol, mon lapar yu' nono tela sapekol, ka' korang, ka' korang, ka' korang, mon coma neng sapekol, arapa ma' pada bongsombongan, acaca ta' mambhu ongnaongan, lebbi becce' caca seaghuna, nyauwaghi ka jhuba' panyana, arapa arapa, bhujung bada eroma, acaca acaca ngangghuya tatakrama, yu' kanca kakabbhi, yu'kanca pada a alako se aghuna.

"Caca Aghuna" (perkataan yang berguna) is a song which contains an advice that people always careful to speak because of words are not much different from the act. People will be honored or insulted because of his words.

\section{Lea-Baesan}

Arapa ma' nojjhune ta' nyapa, lapola senko' andi' sala, Enja' sengko' ta' apa-rapa, Coma ta' kenceng acaca, Ma' pas akolba'na budi arena, Sapa bara' ro, Namen tales pengghir paghar, Ta' enga' lamba' ro, Aba' males sengka ajhar, Sapa bara' ro, Mano' keddhi' ca'lonca'an,

Ta' enga' lamba' ro,

Mon ta' andi' ta'- penta'an

The song above advised young generations not to be lazy in looking for science in order that they will not be regret when they are $\operatorname{adult}(\mathrm{Ta}$ ' enga' lamba' ro, Aba' males sengka ajhar). Besides, the song les belesan has advices in generally for madurese people in order that they must regard the relativeness in their relationship, and they have to help each other to overcome the problems of life.

\section{Entar Akarang}

Entar akarang bula, nyareya kerrang bula, Ka pengghir sereng, ta' osa nyambi bella, mong yambi kereng, olle pas teng-teng,

$\mathrm{Du}$, senneng areng bhareng ca kanca, Nyare engon abhanto oreng tuwa, Tanembhang enmaenan malolo, Mowang bakto parcoma ta' aghuna, Maddha dhuliyan kanca

Aeng pon sorot, makko ombai caraca, Kenneng pancale

The song "Entar Akarang"(pergi mencari kerang) is a song which tells the regular activities of adults and children who live in seaside to look for shells. The activities are usually done when the sea subsided and they are done it by group.

\section{Pacakang Alako \\ Klaban dhasar Pancasila to \\ Dhang-Undhang Dhasar Empa' \\ Lema' Esse'e kamardhika'an}




\section{JIBS}

Indonesia abhangon e sabbhan bidang. Settong naghara se rajha, pon kalonta da' manca naghara, ngasellaghi kabhutowan searopa: sandhang pangan ban laenna. Dari jhau katengal mentamenan tombu ghumbhus rampa' cengngar ngabhiru. Nandhaaghi jha' bhume Indonesia tanaepon sanget landhu. Oh, potra potre sadhaja nyara sroju' pacakang alako, nyopre kantos abhukte settong masyarakat, adhil ma'mor pada melo.

"Pacakang Alako" (semangat bekerja) tell us the condition of Indonesia which is rich in natural resources. This song inspires the spirit of the people of Indonesia to establish the independence of the Republic of Indonesia based on Pancasila and the 1945 Constitution.

\section{Moral and Educational Value Found on Madura Folk song by R. Amirudin Tjitraprawira.}

There are three songs which contains moral educational values for the people of Madura. The songs are "Tondu' Majang, pajjer lagghu and Entar Akarang".

In the song "Tondu ' Majang" has a deep meaning of the character of the Madurese community in carrying out their daily life as a fisherman. Their lives as fishermen are very hard because they have to face the dangers of the sea (atemmo bhabhaja).

In the song was revealed tenacity and spirit of the Madurese fishermen who never afraid to face all risks and hazards that can threaten their lives while fishing at sea. Rigors waves, sea winds, hot sun, and cold rain did not dampen their desire to go to sea. For those waves are like pillows, while the wind like a
Jurnal Ilmiah Bahasa dan Sastra

ISSN : $\mathbf{2 3 5 5 7 0 8 3}$

Volume 2 Nomor 1 Juni 2015

blanket. It is found in the lyrics of the song Abantal omba' asapo' angen.

Moral values contained in this song is the value of responsibility which must Madura coastal communities to sea every day to feed the children and their families at home althought their lives become stake but they have to work because they have wives and children who need living.

While the value of education that we can make an example in this song are the courage and strength mental to face of all the dangers. It is found in the lyrics of the song (Abantal omba ' asapo ' angen).

Moral values in pajjher lagghu song are the value of responsibility and obligation to work as a farmer because the work is an obligation for them to make this nation prosperous. It can be found in the lyrics of "A jhalananna ghi ' syarat kawajibhan. Atatamen mabannya'Hasel bhumena Mama'morna nagharana bangsana". And patience of Madura farmers in managing their farms which infertile can be a lesson for us to remain steadfast in working.

In the song " entar Akarang " there are several educational values contained in this track include the value of togetherness and mutual help among their peers for looking shells activity which is done in groups at night.

\section{Conclusions}

First, "tondu' majang song lyric" In this song was revealed tenacity and spirit of the Madurese fishermen who never afraid to face all risks and hazards that can threaten their lives while fishing at sea. Second, "pajjer lagghu song lyric", the song tells about the persistence of Madura farmer and their strength spirit to farm. Third, "entar akarang 
song lyric" tells about the activities of madurese community who live in the seaside when they do not sail to the sea. 


\section{Jurnal Ilmiah Bahasa dan Sastra \\ ISSN : 23557083 \\ Volume 2 Nomor 1 Juni 2015}

\section{REFERENCES}

Baihaqi, Moch. 2005. An Analyzing on Moral Value of Madurese Folklore. Malang : Malang University

R. Amirudin Tjitraprawira dk., Kumpulan Lagu-lagu Madura, Lembaga Pelestarian Kebudayan Madura, Jakarta, 203.

Baldwin, Timothy. 2003. Lexical Semantics: Introduction. Melbourne: The University of Melbourne Press.

Barker, Chris. 2001. Lexical Semantic. USA: University of California, San Diego Press.

Cruse, D.A. 1986. Lexical Semantics. Cambridge: Cambridge University Press.

Goddard, Cliff. 1998. Semantic Analysis.

New York. Oxford University Press Inc.

Hurford and Heasely, 1984. Semantics. A Course Book. Cambridge: Cambridge University Press. Kempson, Ruth. 1977. Semantic Theory. London: Cambridge University Press.

Korzbsky, Alfred. 1993. Science and Sanity- An Introduction to Non Aristotelian Systems and General Semantics. International Society for General Semantics

Moeloeng, L.J, 2002. Methode Penelitian Kualitatif. Bandung: Remaja Rosdakarya.

Werzbicka, A. 1996. The Primitive of Linguistic Meaning, Semantic: Prime and Universals. Oxford: Oxford University Press.

Leys, Weyne. 1938. Types of Moral Value and Moral Inconsistency. http://www.jstor.org

Luxemburg, Jan Van, dkk. 1989. Pengantar Ilmu Sastra. Terjemahan Dick Hartoko. Jakarta : Gramedia

Abdullah, Irwan, dkk. 2008. Agama dan Kearifan Lokal Dalam Tantangan Global. Yogyakarta : Pustaka Pelajar

Abrams, M.H. A Glossary of Literary Terms. New York : Holt, Rinehart, and Winston

Anderson, Frederick. 1938. The Journal of Philosophy. Retrieved June 29, 2013, from http://www.jstor.org

Carpenter Jack and Neumayer. 1974. Elements of Fiction. Lowa :Brown Company Publisher

Chomsky, Noam. 2009. Language. Retrieved May 11, 2013, from http://www.chomskydefinition.com 
Ekowati, Lilik. 2000. An Analysis of Moral Value in "Jaka Seger and Rara Anteng”, "Dongeng Roro Wayi", and "Dewi Jatiwangi" from Tengger. Malang : Malang University

Essay. 2011. Retrieved May 25, 2013, from http://en.wikipediaEssay.org

Essay. 2011. Retrieved May 25, 2013, from http://en.wikipediaValue.org

Hidayati, Tria W. 2009. An Analysis of Moral Values in East Java Folklores. Malang : Malang University

Importance of Research. 2013. Retrieved May 12, 2013, from http://lifestyle.iloveindia.com/lounge/importance-of-literature

Indonesia. 2011. Retrieved May 25, 2013, from http://id.wikipediaNusantara.org

Legenda. 2011. Retrieved May 25, 2013, from http://id.wikipediaLegenda.org

Leys, Weyne. 1938. Types of Moral Value and Moral Inconsistency. http://www.jstor.org

Literature. 2010. Retrieved May 11, 2013, from http://www.scribd.com

Luxemburg, Jan Van, dkk. 1989. Pengantar Ilmu Sastra. Terjemahan Dick Hartoko. Jakarta : Gramedia

Moral Religion. 2011. Retrieved September 15, 2013, from http://en.wikipediaReligion.org

Moral. 2011. Retrieved September 15, 2013, from http://en.wikipediamoralpsychology.org

Nilai Sosial. 2011. Retrieved May 25, 2013, from http://id.wikipedianilaisosial.org

Norm. 2011. Retrieved September 15, 2013, from http://en.wikipedianormsocial.org

Nugroho, Andika, dkk. 2010. Analisis Nilai-Nilai Pendidikan Novel Sang Pemimpi Karya Andrea Hirata. Surakarta : Fakultas Keguruan dan Ilmu Pendidikan. Universitas Sebelas Maret

Peridian, Olman. 2011. Konsep Pendekatan dan Metode Analisis dalam Karya Sastra. http://www.pengertian-cerita-rakyat.com

Philosophy. 2010. Retrieved September 17, 2013, from http://AllaboutPhilosophy.org

Rahmawati, Evi. 2005. Analyzing on Theme, Messege and Characters Motivation on Vicky Cristina Barcelona Movie. Malang : Kanjuruhan University

Ramadhan, Syahrul. 2002. Kamus Lengkap Peribahasa Indonesia. Surabaya : Amelia 
Sapir, Edward. 1921. Language An Introduction to the Study of Speech. http://www.bartleby.com

Sastra. 2011. Retrieved May 25, 2013, from http://id.wikipediaSastra.org

Shaihan, Moh. 2009. Love Value of the Main Characters in the Novel Shanghai Baby Written by Wei Hui. Malang : Kanjuruhan University

$\begin{array}{llllll}\text { Stewards. } & 2009 . & \text { Values. } & \text { Retrieved } & \text { June } & \end{array}$ http://faculty.stedwards.edu/ursery/phil2329/values

Trisnawati. 2008. The Analysis of Conflicts Found in John Grisham's the Pelican Brief. Malang : Kanjuruhan University

Ursery, Denny. 2002. Exploring Values, Rules and Principles. Retrieved May 11, 2013, from http://teachersites.schoolworld.com/2013/languagearts

Value. 2011. Retrieved May 25, 2013, from http://en.wikipediavalue.org

Woody, Hanna. 2012. Literature. Retrieved May 10, 2013, from http://hanawoody.com 